\title{
AQUEOUS LEAF EXTRACT OF SENDUDUK (Melastoma malabathricum L.) COULD IMPROVE THE PHYSICOCHEMICAL PROPERTIES OF BEEF SAUSAGE DOUGH
}

\author{
Suharyanto $^{1), *}$, Henny Nuraini ${ }^{2)}$, Tuti Suryati ${ }^{2)}$, Irma Isnafia Arief ${ }^{2)}$, Dondin Sajuthi $^{3)}$ \\ 1) Department of Animal Science, Faculty of Agriculture, University of Bengkulu, Jl. WR. Supratman Kandang \\ Limun, Kec. Muara Bangka Hulu, Kota Bengkulu, Bengkulu, Indonesia, 3371A \\ ${ }^{2)}$ Department of Animal Production and Technology, Faculty of Animal Science, IPB University, Jl. Agatis, \\ Babakan, Kec. Dramaga, Bogor, Jawa Barat, Indonesia, 16680 \\ ${ }^{3)}$ Department of Veterinary Clinic Reproduction and Pathology, Faculty of Veterinary, IPB University, Jl. \\ Agatis, Babakan, Kec. Dramaga, Bogor, Jawa Barat, Indonesia, 16680 \\ *Email: suharyanto@unib.ac.id
}

Submitted 22 April 2020; Accepted 22 June 2020

\begin{abstract}
Improving comminuted meat products characteristics using a natural agent, such as phytochemicals, in order to replace the use of nitrite, have become a need due to the health reason. The quality of the sausage is also affected by the initial characteristics of the dough. Therefore, this research was conducted to investigate the effect of aqueous leaf extract of senduduk (Melastoma malabathricum L.) on the physicochemical properties of beef sausage dough. Different four formulas as treatment were employed to form the dough: formula A was as a control consisted of beef meat, vegetable oil, skim milk powder, tapioca, salt, phosphate, and seasoning; formula $\mathrm{B}$ was control added with extract $0.55 \%$; formula $\mathrm{C}$ was control added with sodium nitrite $0.0011 \%$, and formula $\mathrm{D}$ was control added with extract $0.55 \%$ and sodium nitrite $0.0011 \%$. All ingredients were blended to be the dough. The result of the study denoted that the extract $(\mathrm{B}$ and $\mathrm{D})$ significantly decreased $(\mathrm{P}<0.05) \mathrm{pH}$, and $\mathrm{a}_{\mathrm{w}}$ value with no difference in water content among the dough. The total phenolic content of the dough containing extract (B and D) was markedly higher $(\mathrm{P}<0.05)$ than were others. It increased significantly on antioxidant capacity, scavenging activity, and reduced the thiobarbituric acid reactive substances (TBARS) value of the dough. There was also no nitrite residual detected in all dough. In conclusion, the extract could improve the physicochemical properties of beef sausage dough and replace the use of nitrite in the dough.
\end{abstract}

Keywords: Antioxidant; nitrite replacement; Melastoma malabathricum; physicochemical; sausage 


\section{INTRODUCTION}

Sausage has been becoming a popular food in Indonesia. It can be found in an abundance of places and levels of society. Sausage has also come to be a daily diet menu of Indonesian. It is a positive circumstance since it can intensify the protein consumption of Indonesia people. Unfortunately, most of the commercial sausages were manufactured by including the synthetic food additive, which has negative side effects. Some are carcinogenic (De Mey et al., 2014), inducing metabolic disorders (Shalaby and Shanab, 2013), and triggering colorectal disease (Herrmann et al., 2015; Zhu et al., 2014).

Recently, the use of natural agents such as phytochemicals as preservative and antioxidant have been rising for food purposes. The increased use of natural agents is due to awareness of the health of consumers. Accordingly, it is critical to shift to a natural agent in which one of them is senduduk (Melastoma malabathricum L.) leaf extract (SLE). Traditionally, senduduk leaf is utilized for healing diarrhea, dysentery, wounds, sore legs, and thrush (Susanti et al., 2008). Therefore, the exploration of senduduk leaf is focalized on the pharmacological aspect. Many researchers reported that the SLE contains the phenolic compounds which be able to scavenge free radical and inhibit the oxidation process, as well as anti-bacteria both in vitro and in vivo assay (Alnajar et al., 2012; Alwash et al., 2014; Wong et al., 2012; Zakaria et al., 2011). Even, SLE does not cause any acute toxicity and safety (Alnajar et al., 2012; Alwash et al., 2014; Kamsani et al., 2019). For food purposes, Suharyanto et al. (2019) noted that the maceration using water as a solvent also yielded SLE containing phenolic substances and could inhibit the bacteria growth. This result can promote the intensified efforts of SLE utilization in food and magnify safety and healthy food. The necessity of using aqueous extract is to evade consumers from the negative effects of organic solvent residues in the extract (Anyanwu et al., 2017).

On the other hand, the characteristics of the sausage are also determined by the dough quality. The use of SLE in the dough will in turn influence the final product of the food. Therefore, examining the effect of SLE on the sausage dough is fundamental to provide an impact on the sausage product. The aim of the study was to assess the effect of aqueous leaf extract of senduduk (Melastoma malabathricum L.) on the physicochemical properties of beef sausage dough.

\section{MATERIALS AND METHODS}

\section{Extract preparation}

The senduduk leaf collected from shrub in Bengkulu were purified from undesired materials or substances. The clean leaves were air-dried for $5-6 \mathrm{~h}$ at $45^{\circ} \mathrm{C}$. The dried leaves were then powdered and sieved into a 35 mesh. The technique of extraction adopted from Doughari and Manzara (2008). The powder $(40 \mathrm{~g})$ were macerated using distilled water $(400 \mathrm{~mL})$ in $1000 \mathrm{~mL}$ Erlenmeyer flask in the dark and room temperature for $24 \mathrm{~h}$. The macerate was filtered using whatman No. 1 filter paper. The filtrate solvent was evaporated using a rotary evaporator (Heidolph, Antrieb-WMikro, Germany) at $40^{\circ} \mathrm{C}$. The viscous raw extract obtained was freeze-dried (Snijders Scientific, LY5FME, the Netherlands). The extract was stored at $-25^{\circ} \mathrm{C}$ until use.
*Corresponding author:

Suharyanto

Email: suharyanto@unib.ac.id

Department of Animal Science, Faculty of Agriculture, University of Bengkulu, Jl. WR. Supratman Kandang Limun, Kec. Muara Bangka Hulu, Kota Bengkulu, Bengkulu, Indonesia, 3371A
How to cite:

Suharyanto., Nuraini, H., Suryati, T., Arief, I. I., \& Sajuthi, D. (2020). Aqueous Leaf Extract of Senduduk (Melastoma malabathricum L.) Could Improve the Physicochemical Properties of Beef Sausage Dough. Jurnal Ilmu dan Teknologi Hasil Ternak, 15 (2), 8696 


\section{Dough preparation}

The round meat of Brahman Cross was separated from connective and fat tissue and then was cut into small pieces. The cut meat was minced using a meat mincer and further was formulated with the ingredients as shown in Table 1. Four formulas were employed in the research: formula $\mathrm{A}$ as a control consisted of beef, vegetable oil, skim milk powder, tapioca, salt, phosphate, and seasoning; formula B was control added with SLE $0.55 \%$; formula C was control added with sodium nitrite $0.0011 \%$, and formula D was control added with SLE $0.55 \%$ and sodium nitrite $0.0011 \%$. All ingredients were blended to be the dough for each formula.

\section{Measurement of $\mathbf{p H}, \mathbf{a}_{\mathrm{w}}$, and water content}

The dough $\mathrm{pH}$ was determined by adopting AOAC (2005) procedure. A total of $10 \mathrm{~g}$ of sausage dough was dissolved and homogenized in $100 \mathrm{~mL}$ of distilled water. The solution was filtered using filter paper and the $\mathrm{pH}$ filtrate was measured using $\mathrm{pH}$ meter (Schott Instrument Lab 850). The measurement of $\mathrm{a}_{\mathrm{w}}$ was performed using $\mathrm{a}_{\mathrm{w}}{ }^{-}$ meter (Novasina Ms-1) calibrated previously (Lorenzo et al., 2014). The dough was put in the $a_{\mathrm{w}}$-meter holder and measured. Water content was determined using AOAC (2005) method.

\section{Total phenolic content}

Sample preparation was carried out by dissolving $1 \mathrm{~g}$ dough into $5 \mathrm{~mL}$ of absolute methanol for $24 \mathrm{~h}$ (Sukisman et al., 2014). The solution was then filtered and the filtrate was used for determining the total phenolic content by using Al-Saeedi and Hossain (2015) procedure with a slight modification. Briefly, $0.4 \mathrm{~mL}$ of the filtrate was reacted with $3 \mathrm{~mL}$ of $20 \%$ Folin-Ciocalteou (Merck KGaA, Germany) solution and let stand for $5 \mathrm{~min}$.

Table 1. The ingredient of the sausage dough

\begin{tabular}{lcccc}
\hline \multirow{2}{*}{ Materials } & \multicolumn{4}{c}{ Formulas } \\
\cline { 2 - 5 } & A & B & C & D \\
\hline Beef meat (g) & 500 & 500 & 500 & 500 \\
Vegetable oil (g) & 100 & 100 & 100 & 100 \\
Skim milk (g) & 30 & 30 & 30 & 30 \\
Tapioca (g) & 75 & 75 & 75 & 75 \\
Cubic ice (g) & 175 & 175 & 175 & 175 \\
Salt (g) & 15 & 15 & 15 & 15 \\
Garlic (g) & 8.75 & 8.75 & 8.75 & 8.75 \\
White pepper (g) & 1 & 1 & 1 & 1 \\
Nutmeg (g) & 2.5 & 2.5 & 2.5 & 2.5 \\
Phosphate (g) & 1.5 & 1.5 & 1.5 & 1.5 \\
NaNO2 (g) (0.0011\%)* & - & - & $\mathbf{0 . 0 1}$ & $\mathbf{0 . 0 1}$ \\
Extract (g) (0.55\%)* & - & $\mathbf{5}$ & - & $\mathbf{5}$ \\
\hline Descriptionyyy
\end{tabular}

Description: * Based on the total ingredient (908.75 g).

The mixture was added with $3 \mathrm{~mL}$ of $10 \% \mathrm{Na}_{2} \mathrm{CO}_{3}$ solution, and then incubated for $60 \mathrm{~min}$ in a dark and room temperature. The mixture was absorbed using a spectrophotometer (Agilent, UV-Vis 8453, USA) at a wavelength of $760 \mathrm{~nm}$. A similar procedure was applied to various standard gallic acid concentrations $(0-16 \mathrm{mg} / \mathrm{mL})$. The total phenolic content was calculated using a linear regression equation of the gallic acid absorbance and expressed in $\mathrm{mg}$ equivalent gallic acid/100 g dough dry matter.

\section{Antioxidant activity}

Sample preparation was employed using Sukisman et al. (2014) procedure. One-gram dough was dissolved into $5 \mathrm{~mL}$ of 
absolute methanol for $24 \mathrm{~h}$. The solution was filtered and the filtrate was used for antioxidant capacity determination (Mahmoudi et al., 2016). As much as $0.2 \mathrm{~mL}$ of sample-methanolate solution was mixed with $1.8 \mathrm{~mL}$ of DPPH-methanolate solution (Sigma-Aldrich, D9132-1G, Germany) at a concentration of $6 \times 10^{-5} \mathrm{~mol} / \mathrm{L}$ and shaken for $20 \mathrm{~s}$.

The mixture was incubated in a dark and room temperature for $60 \mathrm{~min}$. It was then measured for absorbance using a spectrophotometer (Agilent, UV-Vis 8453, USA) at a wavelength of $517 \mathrm{~nm}$. In the same way, standard butylated hydroxytoluene (BHT) (Himedia, GRM797-500G, India) solutions in various serial dilutions $(0.0-4.5 \mathrm{mg} / 100 \mathrm{~mL})$ were employed.

Percent scavenging activity was calculated by the formula [( $\mathrm{A}_{\text {control- }}{ }^{-}$ $\left.\left.\mathrm{A}_{\text {sample }}\right) / \mathrm{A}_{\text {control }}\right] \times 100$ where $\mathrm{A}_{\text {control }}$ was the absorbance of the DPPH solution without dough and $\mathrm{A}_{\text {sample was the absorbance of the }}$ dough. The antioxidant capacity of the dough was calculated using the linear regression equation of BHT as a standard and expressed as mg equivalent BHT/100 $\mathrm{g}$ dry matter.

\section{Thiobarbituric acid reactive substances (TBARS) value}

Thiobarbituric acid reactive substances (TBARS) assay was employed for measuring malondialdehyde content by using Turgut et al. (2016) procedure. A-5 g dough was homogenized in $15 \mathrm{~mL}$ of distilled water and centrifuged at $2000 \times \mathrm{g}$ for $15 \mathrm{~min}$. As much as $1 \mathrm{~mL}$ of the supernatant of the mixture was added with $2 \mathrm{~mL}$ of $0.25 \mathrm{M} \mathrm{HCl}$ containing thiobacbituric acid (TBA) $(0.375 \%, \mathrm{w} / \mathrm{v})$ and trichloroacetic acid (TCA) $(15 \%, \mathrm{w} / \mathrm{v})$ and then added with $3 \mathrm{~mL}$ of BHT $2 \%$.

The tube was vortexed and incubated at $100^{\circ} \mathrm{C}$ for $15 \mathrm{~min}$. The mixture was cooled at room temperature and then centrifuged at $1000 \times g$ for $10 \mathrm{~min}$. Finally, it was measured for absorbance using a spectrophotometer (Agilent, UV-Vis 8453,
USA) at a wavelength of $531 \mathrm{~nm}$ against the blind. TBARS were calculated using 1, 1, 3, 3-tetraethoxypropane standard curve (concentration $2 \times 10^{-6}$ to $10 \times 10^{-6} \mathrm{M}$ ) and expressed as $\mathrm{mg}$ malondialdehyde (MDA)/kg of dough.

\section{Nitrite residual}

The nitrite residual of the sausage dough was determined by AOAC (2005) procedure. A-5 $\mathrm{g}$ of sausage dough was added with $40 \mathrm{~mL}$ of distilled water and heated to reach $80^{\circ} \mathrm{C}$. The solution was transferred to a $500 \mathrm{~mL}$ volumetric flask and hot distillate water was added until the volume reached $300 \mathrm{~mL}$. The flask containing the solution was put into the steam bath for $2 \mathrm{~h}$ and stirring occasionally. The solution was cooled at room temperature and then was filtered.

Twenty-five $\mathrm{mL}$ of filtrate was put in the $50 \mathrm{~mL}$ volumetric flask, added with $2.5 \mathrm{~mL}$ of sulphanolate and stand for $5 \mathrm{~min}$. Then, a reagent of $2.5 \mathrm{~mL} \mathrm{~N}$ - (1-Naphthyl) ethylenediamine (NED) $2 \mathrm{HCl}$ is added and homogenized and reached to the mark. The solution was allowed to stand for $15 \mathrm{~min}$ to form pink and then its absorbance was measured using a spectrophotometer (Agilent, UV-Vis 8453, USA) at a wavelength of $540 \mathrm{~nm}$.

An equivalent procedure was applied for blanks of $45 \mathrm{~mL}$ of distilled water, $2.5 \mathrm{~mL}$ of sulphanilamide solvents, and $2.5 \mathrm{~mL}$ of NED solvents. Standard curves from $\mathrm{NaNO}_{2}$ solution (Sigma-Aldrich, Germany) with a serial concentration of 0.2 ; $0.4 ; 0.6 ; 0.8 \mu \mathrm{g} / \mathrm{mL}$ was applied like the sample. Nitrite content was calculated based on the standard curve regression equation and expressed in $\mathrm{mg} / \mathrm{kg}$ of dry matter.

\section{Statistical analysis}

The experiment was designed by using a completely randomized design with three replications of each treatment. The data presented as mean with standard deviations. The data were analyzed by oneway ANOVA and the differences of treatments were continued with multiple 
comparisons Tukey test. The significant difference was set at $p<0.05$. The statistical analysis using the general linear model of SAS, version 9.3.

\section{RESULTS AND DISCUSSION}

\section{Value of $\mathbf{p H}, \mathrm{a}_{\mathrm{w}}$, and moisture content}

The addition of SLE improved physical characteristics. The data in Table 2 depict that the incorporation of SLE and nitrite in the dough decrease the value of $\mathrm{pH}$, $\mathrm{a}_{\mathrm{w}}$, and water content of the dough. The SLE in the dough was a factor determining the physical properties of the dough. Formula B which is a dough containing SLE had a lower value than control (formula $\mathrm{A}$ ) in $\mathrm{pH}$ and $\mathrm{a}_{\mathrm{w}}$ variables. The nitrite addition just only affected on the dough if it was mixed with the SLE (formula D). It was supported by the data Formula $\mathrm{C}$ which statistically not different from Formula A. The capability of SLE to lower the $\mathrm{pH}$ value of the dough was likely influenced by the phenolic compounds of the SLE. Aqueous extract of senduduk leaf hold phenolic compounds (Suharyanto et al.,, 2019) which capable of decreasing $\mathrm{pH}$ value of extract (Wang et al., 2015). The lessen of $\mathrm{pH}$ value is contributed by the hydroxyl group of phenolic compounds of the extract (Pereira et al., 2009). This result supported other studies of plant extracts that decrease the $\mathrm{pH}$ value of food product (Devatkal et al., 2010; Jung and Joo, 2013). It was also confirmed that the SLE $\mathrm{pH}$ measured was 4.1 at a concentration $500 \mathrm{mg} / \mathrm{mL}$ (data not shown).

The addition with nitrite to formula $\mathrm{C}$ also indicated the lower $\mathrm{pH}$ than control. Nitrite in meat products dissolves and form $\mathrm{HNO}_{2}$ (nitrous acid) to produce NO (nitric oxide) and $\mathrm{NO}_{2}$ (nitrite) (Honikel, 2008). The NO molecule reacts with myoglobin or amino acids, while $\mathrm{NO}_{2}$ reacts with water to re-form $\mathrm{HNO}_{2}$ and $\mathrm{HNO}_{3}$ (nitric acid) (Honikel, 2008). These compounds make the product more acidic (Suryati et al., 2014).

Table 2. The mean of $\mathrm{pH}$, aw, and water content of the sausage dough added with SLE

\begin{tabular}{cccc}
\hline Formulas & $\mathrm{pH}$ & $\mathrm{a}_{\mathrm{w}}$ & Water content $(\%)$ \\
\hline $\mathrm{A}$ & $5.97 \pm 0.08^{\mathrm{a}}$ & $0.89 \pm 0.005^{\mathrm{a}}$ & $63.18 \pm 0.77^{\mathrm{a}}$ \\
$\mathrm{B}$ & $5.85 \pm 0.01^{\mathrm{b}}$ & $0.87 \pm 0.010^{\mathrm{bc}}$ & $62.13 \pm 0.45^{\mathrm{ab}}$ \\
$\mathrm{C}$ & $5.89 \pm 0.01^{\mathrm{ab}}$ & $0.88 \pm 0.002^{\mathrm{ab}}$ & $61.67 \pm 0.04^{\mathrm{b}}$ \\
$\mathrm{D}$ & $5.83 \pm 0.02^{\mathrm{b}}$ & $0.85 \pm 0.004^{\mathrm{c}}$ & $62.12 \pm 0.14^{\mathrm{ab}}$ \\
\hline
\end{tabular}

Description: Data are shown as mean \pm standard deviation. Different superscripts in the same column indicate a significant difference $(\mathrm{P}<0.05)$.

Water activity $\left(a_{w}\right)$ of the product is one of the essential factors affecting the shelf life. The lower the value of $\mathrm{a}_{\mathrm{w}}$, the better the quality of the food product is obtained. This study elucidated that SLE improved the $a_{w}$ value of the sausage dough. The inclusion of SLE with or without nitrite combination reduced $a_{w}$ value of the dough. The control (formula A) gained similar $\mathrm{a}_{\mathrm{w}}$ value from nitrite addition (formula $\mathrm{C}$ ). It indicated that SLE as a determinant of the decline $a_{w}$ value. The low $a_{w}$ value of dough added with SLE was due to the addition of extracts. The extract reduced the presence of free water in the dough that most probably caused by phenolic compounds forming hydrogen bonds with water molecules (Andarwulan and Faradilla, 2012). The water content of the dough added with SLE (Formula B and D) and control (Formula A) had similar value. However, the dough containing SLE also gave similar value to the nitrate-containing dough. Generally, the addition of SLE could not affect the water content of the dough.

In this case, nitrite decreased the water content of the dough. This phenomenon revealed that the quality of the dough added with SLE had better physical quality, which indicated by the lower $\mathrm{pH}$ and $\mathrm{a}_{\mathrm{w}}$ value. Reducing water content economically will result in the loss of production. 


\section{Total phenolic content}

The addition of SLE in the sausage dough increased the total phenolic content. The mean of total phenolic content of all dough are shown in Table 3 . The result exhibited that formula $B$ reached the highest phenolic content. It is most likely due to the contribution of SLE in the dough. Suharyanto et al. (2019) extracted senduduk leaf using water as a solvent and the result exerted phenolic compound in the extract. Other researchers were also found that water extracts of plants yielded plant extract with phenolic compounds held (Anggraini, 2017; Mariem et al., 2014; Nurdiana and Marziana, 2013).

Formula $\mathrm{A}$ and $\mathrm{C}$ that were not be added with SLE contained comparable phenolic compounds but they were lower than the formula blended with SLE (formula $B$ and D). Although not added with SLE, formula $\mathrm{A}$ and $\mathrm{C}$ contained phenolic compounds. Those were most likely contributed by the seasons. Suryati et al. (2014) stated that seasons also play a vital role by contributing the phenolic compounds to the product.

The combination of senduduk leaf extract and nitrite reduced precisely extract role in contributing phenolic compounds. The decrease in the total phenolic content of formula $\mathrm{D}$ was most probably caused by nitrosation of the phenolic compound (González-Mancebo et al., 2002) and a little water proved to be important in the initial period of the reaction (Ji et al., 2011). Nitrosation might be mediated by the lower $\mathrm{pH}$ of the obtained result. GonzálezMancebo et al. (2002) stated that nitrosation could be inhibited by the rising $\mathrm{pH}$ value. The study exhibited that the combination of SLE and nitrite exerted the lowest $\mathrm{pH}$ value of the dough (as shown in Table 2). This condition promoted the lower of existing phenolic compounds through a nitrosation process.

Table 3. The mean of total phenolic content, scavenging activity, and antioxidant capacity of the sausage dough added with SLE

\begin{tabular}{cccc}
\hline Formula & $\begin{array}{c}\text { Total phenolic content }(\mathrm{mg} \\
\text { GAE/100 g dry matter) }\end{array}$ & $\begin{array}{c}\text { Scavenging } \\
\text { activity }(\%)\end{array}$ & $\begin{array}{c}\text { Antioxidant capacity }(\mathrm{mg} \\
\text { BHTE/100 g dry matter) }\end{array}$ \\
\hline A & $130.12 \pm 10.24^{\mathrm{c}}$ & $24.24 \pm 2.65^{\mathrm{b}}$ & $36.11 \pm 2.11^{\mathrm{b}}$ \\
B & $180.65 \pm 1.78^{\mathrm{a}}$ & $43.19 \pm 2.85^{\mathrm{a}}$ & $62.90 \pm 1.49^{\mathrm{a}}$ \\
C & $124.05 \pm 10.70^{\mathrm{c}}$ & $25.86 \pm 1.44^{\mathrm{b}}$ & $37.09 \pm 0.45^{\mathrm{b}}$ \\
D & $143.02 \pm 10.63^{\mathrm{b}}$ & $42.49 \pm 1.83^{\mathrm{a}}$ & $62.28 \pm 0.74^{\mathrm{a}}$ \\
\hline
\end{tabular}

Description: Data are shown as mean \pm standard deviation. Different superscripts in the same column indicate a significant difference $(\mathrm{P}<0.05)$; GAE $=$ Gallic acid equivalent; $\mathrm{BHTE}=\mathrm{BHT}$ equivalent.

\section{Antioxidant capacity and scavenging activity}

The existence of phenolic compounds in the dough added with SLE affected the antioxidant capacity and scavenging activity of the dough. Antioxidant capacity expresses the concentration of antioxidants in the extract that equivalent to BHT. Scavenging activity shows the percentage of the capability of antioxidant in the extract to scavenge DPPH free radical. These data are shown in Table 3. The pattern of the antioxidant capacity and scavenging activity were similar to those phenolic compounds of the dough. The higher phenolic compounds held in the dough the higher the antioxidant capacity and scavenging activity of the dough. This study indicated that the addition of SLE significantly enhanced the antioxidant capacity and scavenging activity of the dough as shown by formula B and D. This result revealed that SLE in the dough played a role in increasing antioxidant activity.

This role was acted by phenolic compounds of the SLE. As mentioned above, the SLE contained phenolic compounds and these compounds could 
increase the antioxidant activity of plant extract (Alnajar et al., 2012; Zakaria et al., 2011). This research result also showed that nitrite had a low effect on the antioxidant activity (antioxidant capacity and scavenging activity) of the dough. The antioxidant activity was not different from control (formula A).

Nitrites can actually act as antioxidants (Karwowska et al., 2020). The addition of nitrite can form $\mathrm{NO}$ which in the lipid oxidation mechanism will form ROONO (Patel et al., 2000), but the role of these antioxidants is probably inhibited by the presence of phenolic compounds. This is because NO can react with phenolic compounds to form nitroso compounds from phenolic (González-Mancebo et al., 2002). These derived compounds apparently cannot act as antioxidants (Zubillaga et al., 1984).

\section{TBARS value and nitrite residual}

The result of the study showed that the TBARS value was significantly different lower of dough added with SLE from not added. The lower value of TBARS indicating the lower MDA production. MDA is one of lipid oxidation and this is a marker to determine the lipid oxidation. TBARS is indicated by the MDA production and expressed as mg MDA $/ \mathrm{kg}$ of dough (Table 4).

The low TBARS value of dough added with SLE due to phenolic compounds in SLE acts as an antioxidant by preventing the oxidation process (Alnajar et al., 2012; Alwash et al., 2014; Zakaria et al., 2011). The TBARS value of the dough added with SLE confirmed that the phenolic compounds of the SLE capable of antioxidants role. The capability of phenolic compounds is due to the hydroxyl group structure of these compounds (Bendary et al., 2013). The phenolic compounds donate hydrogen and react to reactive species in the termination reaction to break down the new radical formation cycle (Pereira et al., 2009). However, TBARS values of all doughs were below the detectable threshold of rancidity, which is $5 \mathrm{mg} \mathrm{MDA} / \mathrm{kg}$ (Insausti et al., 2001).

Table 4. The mean of TBARS value and nitrite residual of the sausage dough added with SLE

\begin{tabular}{ccc}
\hline Formula & TBARS (mg MDA/kg dry matter) & Nitrite residual (mg/kg dry matter) \\
\hline A & $3.08 \pm 0.075^{\mathrm{a}}$ & $\mathrm{Nd}$ \\
B & $1.41 \pm 0.018^{\mathrm{d}}$ & $\mathrm{Nd}$ \\
C & $1.55 \pm 0.046^{\mathrm{c}}$ & $\mathrm{Nd}$ \\
D & $1.96 \pm 0.060^{\mathrm{b}}$ & $\mathrm{Nd}$
\end{tabular}

Description: Data are shown as mean \pm standard deviation. Different superscripts in the same column indicate a significant difference $(\mathrm{P}<0.05) ; \mathrm{Nd}=$ not detected.

Any nitrite residues in all doughs were not detected as shown in Table 4. This condition was possible due to the amount added was very little so that it was below the detectable threshold of tools and methods. Honikel (2008) stated that the nitrite concentration will decrease by $65 \%$ from the time of incorporation to the heating process finished. In formula $\mathrm{D}$, it was thought to be due to the reduction process by phenolic compounds. Some previous research results suggested that phenolic compounds could reduce nitrites in Dendeng products (Suryati et al.,, 2014) and dry-cured bacon (Wang et al.,, 2015). The factors that caused the detection of nitrite residues in this study were quite complex. Detection of nitrite residues did not indicate that this product is safe from the negative effects of nitrites. The maximum limit of nitrite residual is $30 \mathrm{mg} / \mathrm{kg}$ product weight (BPOM, 2019).

\section{CONCLUSION}

The addition of aqueous extract of senduduk leaf improved the physical and chemical properties of the raw sausage dough. The addition of $0.55 \%$ senduduk leaf 
extract decreased the $\mathrm{pH}, \mathrm{a}_{\mathrm{w}}$, and water content of the dough; enhanced the total phenolic content, antioxidant activity of the dough; and reduced the TBARS value of the dough. The use $0.55 \%$ of senduduk leaf extract could replace nitrite $0.0011 \%$ in the dough physicochemical characteristics. The good characteristics of the dough will generate a good properties of final product.

\section{CONFLICT OF INTEREST}

We declare that there are no conflict of interest in this work.

\section{ACKNOWLEDGMENT}

We grateful to the Ministry of Research, Technology and Higher Education, The Republic of Indonesia, for the supporting on this research through BPPDN Scholarship.

\section{REFERENCES}

Al-Saeedi, A. H., \& Hossain, M. A. (2015). Total phenols, total flavonoids contents and free radical scavenging activity of seeds crude extracts of pigeon pea traditionally used in Oman for the treatment of several chronic diseases. Asian Pacific Journal of Tropical Disease, 5(4), 316-321. https://doi.org/10.1016/S2222-1808(1 4)60790-8

Alnajar, Z. A. A., Abdulla, M. A., Ali, H. M., Alshawsh, M. A., \& Hadi, A. H. A. (2012). Acute Toxicity evaluation, antibacterial, antioxidant and immunomodulatory effects of melastoma malabathricum. Molecules, 17(3), 3547-3559. https://doi.org/10.3 390/molecules 17033547

Alwash, M. S. A., Ibrahim, N., Yaacob, W. A., \& Din, L. Bin. (2014). Antibacterial, antioxidant and cytotoxicity properties of traditionally used Melastoma malabathricum Linn. leaves. Advance Journal of Food Science and Technology, 6(1), 6-12.

Andarwulan, N., \& Faradilla, R. F. (2012). Senyawa Fenolik pada Beberapa Sayuran Indigenous dan Indonesia. SEAFAST Center IPB.

Anggraini, T. (2017). Antioxidant activity of Syzygium oleana. Pakistan Journal of Nutrition, 16(8), 605-611. https:// doi.org/10.3923/pjn.2017.605.611

Anyanwu, S., Inyang, I. J., Asemota, E. A., Obioma, O. O., Okpokam, D. C., \& Agu, V. O. (2017). Effect of ethanolic extract of Chromolaena odorata on the kidneys and intestines of healthy albino rats. Integrative Medicine Research, 6(3), 292-299. https://doi. org/10.1016/j.imr.2017.06.004

AOAC (Association of Official Analytical Chemist). (2005). Association of Official Agricultural Chemists Official methods of analysis of AOAC International (18th ed.). AOAC.

Bendary, E., Francis, R. R., Ali, H. M. G., Sarwat, M. I., \& El Hady, S. (2013). Antioxidant and structure-activity relationships (SARs) of some phenolic and anilines compounds. Annals of Agricultural Sciences, 58(2), 173-181. https://doi.org/10.1016/j.aoas.2013.07.002

BPOM. (2019). Peraturan Badan Pengawas Obat dan Makanan No 11 Tahun 2019 Tentang Bahan Tambahan Pangan. Badan Pengawas Obat dan Makanan.

De Mey, E., De Klerck, K., De Maere, H., Dewulf, L., Derdelinckx, G., Peeters, M.-C., Fraeye, I., Vander Heyden, Y., \& Paelinck, H. (2014). The occurrence of N-nitrosamines, residual nitrite and biogenic amines in commercial dry fermented sausages and evaluation of their occasional relation. Meat Science, 96(2), 821-828. https://doi. 
org/10.1016/j.meatsci.2013.09.010

Devatkal, S. K., Narsaiah, K., \& Borah, A. (2010). Anti-oxidant effect of extracts of kinnow rind, pomegranate rind and seed powders in cooked goat meat patties. Meat Science, 85(1), 155-159. https://doi.org/10.1016/j.meatsci.200 9.12.019

Doughari, J. H., \& Manzara, S. (2008). In vitro antibacterial activity of crude leaf extracts of Mangifera indica Linn. African Journal of Microbiology Research, 4(22), 67-72. https://doi. org/10.5897/AJMR

Herrmann, S. S., Duedahl-Olesen, L., \& Granby, K. (2015). Occurrence of volatile and non-volatile $\mathrm{N}$ nitrosamines in processed meat products and the role of heat treatment. Food Control, 48, 163-169. https://doi.org/10.1016/j.foodcont.20 14.05.030

Honikel, K.-O. (2008). The use and control of nitrate and nitrite for the processing of meat products. Meat Science, 78(1), 68-76. https://doi.org/10.1016/j.meat sci.2007.05.030

Insausti, K., Beriain, M., Purroy, A., Alberti, P., Gorraiz, C., \& Alzueta, M. (2001). Shelf life of beef from local Spanish cattle breeds stored under modified atmosphere. Meat Science, 57(3), 273-281. https://doi.org/10.1016/S03 09-1740(00)00102-9

Ji, L., Qian, C., Liu, M., \& Chen, X. (2011). Highly efficient nitration of phenolic compounds using some nitrates and oxalic acid under solvent-free conditions. Journal of Chemical Research, 35(2), 101-103. https://doi.org/ 10.3184/030823411X12935549795603

Jung, E., \& Joo, N. (2013). Roselle (Hibiscus sabdariffa L.) and soybean oil effects on quality characteristics of pork patties studied by response surface methodology. Meat Science, 94(3), 391-401. https://doi.org/10.10 16/j.meatsci.2013.02.008

Kamsani, N. E., Zakaria, Z. A., Md Nasir, N. L., Mohtarrudin, N., \& Mohamad Alitheen, N. B. (2019). Safety assessment of methanol extract of Melastoma malabathricum L. leaves following the subacute and subchronic oral consumptions in rats and its cytotoxic effect against the HT29 cancer cell line. Evidence-Based Complementary and Alternative Medicine, 2019, 1-14. https://doi.org /10.1155/2019/5207958

Karwowska, M., Kononiuk, A., \& Wójciak, K. M. (2019). Impact of sodium nitrite reduction on lipid oxidation and antioxidant properties of cooked meat products. Antioxidants, 9(1), 9. https: //doi.org/10.3390/antiox9010009

Lorenzo, J. M., Sineiro, J., Amado, I. R., \& Franco, D. (2014). Influence of natural extracts on the shelf life of modified atmosphere-packaged pork patties. Meat Science, 96(1), 526-534. https:// doi.org/10.1016/j.meatsci.2013.08.007

Mahmoudi, S., Khali, M., Benkhaled, A., Benamirouche, K., \& Baiti, I. (2016). Phenolic and flavonoid contents, antioxidant and antimicrobial activities of leaf extracts from ten Algerian Ficus carica L. varieties. Asian Pacific Journal of Tropical Biomedicine, 6(3), 239-245. https:// doi.org/10.1016/j.apjtb.2015.12.010

Mariem, C., Sameh, M., Nadhem, S., Soumaya, Z., Najiba, Z., \& Raoudha, E. G. (2014). Antioxidant and antimicrobial properties of the extracts from Nitraria retusa fruits and their applications to meat product preservation. Industrial Crops and 
Products, 55, 295-303. https://doi. org/10.1016/j.indcrop.2014.01.036

Mason, S. L., Loughran, Ö., \& La Thangue, N. B. (2002). Nitrosation of phenolic compounds: Effects of alkyl substituents and solvent. Monatshefte Fur Chemie, 133(2), 157-166. https:// doi.org/10.1007/s706-002-8245-0

Nurdiana, S., \& Marziana, N. (2013). Wound healing activities of Melastoma malabathricum leaves extract in Sprague dawley rats. International Journal of Pharmaceutical Sciences Review and Research, 20(2), 20-23.

Patel, R. (2000). Mechanisms of the pro- and anti-oxidant actions of nitric oxide in atherosclerosis. Cardiovascular Research, 47(3), 465-474. https://doi. org/10.1016/S0008-6363(00)00086-9

Pereira, D. M., Valentão, P., Pereira, J. A., \& Andrade, P. B. (2009). Phenolics: From chemistry to biology. Molecules, 14(6), 2202-2211.

Shalaby, A. (2013). Antioxidant compounds, assays of determination and mode of action. African Journal of Pharmacy and Pharmacology, 7(10), 528-539. https://doi.org/10.5897/AJPP2013.3474

Suharyanto, Nuraini, H., Suryati, T., Arief, I. I., \& Sajuthi, D. (2019). Antioxidant and antibacterial properties of aqueous extract of senduduk (Melastoma malabathricum L.) leaf from Indonesia for food additive. Pakistan Journal of Nutrition, 18(4), 391-400. https://doi. org/10.3923/pjn.2019.391.400

Sukisman, Purnomo, H., Rosyidi, D., \& Eka Radiat, L. (2014). Quality properties, antioxidant capacity and total phenolic content of traditional deep fried shredded meat (abon) of Palu, Central Sulawesi. American Journal of Food
Technology, 9(2), 80-88. https://doi. org/10.3923/ajft.2014.80.88

Suryati, T., Astawan, M., Lioe, H. N., Wresdiyati, T., \& Usmiati, S. (2014). Nitrite residue and malonaldehyde reduction in dendeng — Indonesian dried meat - influenced by spices, curing methods and precooking preparation. Meat Science, 96(3), 1403-1408. https://doi.org/10.1016/j. meatsci.2013.11.023

Susanti, D., Sirat, H. M., Ahmad, F., Ali, R. M., Aimi, N., \& Kitajima, M. (2008). Erratum to "Antioxidant and cytotoxic flavonoids from the flowers of Melastoma malabathricum L.”. Food Chemistry, 107(3), 1275. https://doi. org/10.1016/j.foodchem.2007.09.009

Turgut, S. S., Soyer, A., \& Işıkçı, F. (2016). Effect of pomegranate peel extract on lipid and protein oxidation in beef meatballs during refrigerated storage. Meat Science, 116, 126-132. https:// doi.org/10.1016/j.meatsci.2016.02.011

Wang, Y., Li, F., Zhuang, H., Chen, X., Li, L., Qiao, W., \& Zhang, J. (2015). Effects of plant polyphenols and $\alpha$ tocopherol on lipid oxidation, residual nitrites, biogenic amines, and $\mathrm{N}$ nitrosamines formation during ripening and storage of dry-cured bacon. LWT - Food Science and Technology, 60(1), 199-206. https:// doi.org/10.1016/j.lwt.2014.09.022

Wong, K.-C., Hag Ali, D. M., \& Boey, P.-L. (2012). Chemical constituents and antibacterial activity of Melastoma malabathricum L. Natural Product Research, 26(7), 609-618. https://doi. org/10.1080/14786419.2010.538395

Zakaria, Z. A., Rofiee, M. S., Mohamed, A. M., Teh, L. K., \& Salleh, M. Z. (2011). In vitro antiproliferative and antioxidant activities and total 
phenolic contents of the extracts of Melastoma malabathricum leaves. Journal of Acupuncture and Meridian Studies, 4(4), 248-256. https://doi.org /10.1016/j.jams.2011.09.016

Zhu, Y., Wang, P. P., Zhao, J., Green, R., Sun, Z., Roebothan, B., Squires, J., Buehler, S., Dicks, E., Zhao, J., Cotterchio, M., Campbell, P. T., Jain, M., Parfrey, P. S., \& Mclaughlin, J. R. (2014). Dietary N -nitroso compounds and risk of colorectal cancer: a casecontrol study in Newfoundland and Labrador and Ontario, Canada. British Journal of Nutrition, 111(6), 11091117. https://doi.org/10.1017/S00071 14513003462

Zubillaga, M., Maerker, G., \& Foglia, T. (1984). Antioxidant activity of sodium nitrite in meat. American Oil Chemists'Society, 61(4), 772-776. 